\title{
Education: An Excellent Opportunity to Respect, Maintain and Promote Indigenous Children's Cultural and Linguistic Richness
}

\author{
Karla Del Carpio \\ Department of World Languages and Cultures, University of Northern Colorado, Greeley, Colorado, United States
}

\begin{abstract}
Education can provide the opportunity to affirm indigenous children's cultural and linguistic identity by using their funds of knowledge as an essential tool in the teaching and learning process. This paper emphasizes the importance of using indigenous children's voices, knowledge, and wisdom to continue to develop their talents and capacities to share, learn, inquire, analyze, and create. To do so, indigenous children should be given the opportunity to participate in meaningful activities that allow them to utilize their native language and culture which can be done through bilingual discussions, debates, artistic works, creation of poems, singing of songs, games and group activities related to their own indigenous culture while using both their native and second languages. Also, critical thinking skills can be developed through the use of this type of activities that can be artistic and also promote collaborative work since bringing the community together is fundamental in the indigenous cosmovision. In addition, the techniques that are suggested in this piece can help create a peaceful/harmonious environment in the classroom where students' affective filters are open to welcome and practice the target language since enriching interactions that embrace diversity in all its dimensions are promoted. Thus, the purpose of this manuscript is to share some ideas to make the teaching and learning process more meaningful, respectful, harmonious, and enjoyable through artistic activities that promote indigenous children's own language, culture and cosmovision. The ideas that will be discussed in this piece are based on a qualitative research study conducted at a Spanish-Indigenous Tsotsil bilingual school in Chiapas, Mexico.
\end{abstract}

Index Terms — children, culture, education, indigenous, language

\section{INTRODUCTION}

In today's society, the list of challenges that one faces is endless; from social, political, economic and ideological challenges to linguistic and cultural ones just to name a few. These challenges, in one way or another, impact how education and the school are conceived and directed. As well as, the tasks of the teacher and the student, especially in bilingual schools where a dominant language such as Spanish and an indigenous language are involved. For instance, in the context of Latin America, which is considered to be one of the culturally and linguistically richest areas in the globe with approximately 400 native groups with an estimated population of 40 million that live in the area (López, 2009). Mexico, the focus of this paper, is considered to be one of the countries with one of the largest indigenous populations in the subcontinent with an estimate of 10 million, which represents between 12\% and 15\% of the Mexican population (Chacón, 2005). National Institute of Statistics and Geography (INEGI) (2010) indicates that there are approximately 6,695,228 inhabitants aged five years old and older who speak an indigenous language (INEGI, 2010), which represents $6.8 \%$ of the population ranked in these ages.

Unfortunately, historically in Mexico, the school and transitional bilingual education have been used to favor the learning of Spanish, putting indigenous languages at a disadvantage, which has affected the linguistic and cultural wealth of the Mexican nation, and this has also been a violation of the human-linguistic and cultural rights of indigenous children. Many times, the value and importance of indigenous languages has been forgotten. In this regard, De Varennes (s.f.) argues that:

Language has a tremendously important role as both gatekeeper and doorway: indigenous peoples may be excluded or disadvantaged where a government limits or refuses to allow the use of an indigenous language within the institutions of the state and relations with the public, or a doorway can be opened in both education and advancement when the use of an indigenous language can serve to empower members of indigenous communities (p.2).

It is important to remember that the prohibition of native languages or their refusal has contributed to the exclusion of indigenous communities from different facets of political, educational, and social life. The exclusion of indigenous peoples and with them their languages and cultures are one of the many reasons why it was considered necessary to carry out the research study that is described in this manuscript.

\section{THE STUDY}




\section{Research Methodology}

The purpose of this qualitative research was to explore the current situation of the Mayan indigenous Tsotsil language by analyzing a Spanish-Tsotsil bilingual program implemented at an elementary bilingual school in Tentic, Chiapas, Mexico. Furthermore, the study analyzed how the indigenous Tsotsil language is preserved or hindered through bilingual education. This was a qualitative ethnographic study that required to live in the_indigenous community at different times. The research question that guided the study was: How is the indigenous Tsotsil language maintained or hindered through bilingual education at a Spanish- Tsotsil bilingual elementary school in Tentic, Chiapas, Mexico?

To collect data for this study, fieldwork was done on the research site. Dewalt and Dewalt (2001 as cited in Kawulich, 2005) argue that fieldwork includes active looking, the improvement of memory, informal conversations (interviews), writing meticulous field notes and patience. Keeping these ideas in mind and considering the purpose of this research, Tsotsil third graders were observed passively and actively and were also interviewed over the course of one semester. The students' teacher was also observed passively when teaching and was interviewed during the semester. In addition, written questionnaires were used and extensive field notes were written during the data collection process. In both the semi-standardized interviews and the open-ended written questionnaires, students were asked about the language(s) they speak, where they use them, and the language they identify themselves with. Moreover, they were asked about the language(s) they speak in school with the teacher and their friends, as well as in different locations with their relatives. Also, they were asked questions about their language preference and attitudes. The semi-standardized interviews were conducted in Spanish and Tsotsil. To ensure communication took place, sixth graders who are fluent in both languages were asked to be present when interviews were conducted with 25 third graders.

As for the teacher and the principal, the interviews were done in Spanish. The teacher was asked, for example, with regards to the purpose of the semester, the subjects she was teaching, the languages she uses when teaching, how she sees the role of the Spanish and Tsotsil languages and cultures in the teaching and learning process and about how her students behave when they are spoken in Spanish or Tsotsil. Also, the instructor was asked about her students' behavior and academic performance during the term. Following Berg's (2009) suggestion, the semi-standardized interviews conducted with participants were very useful as the questions in this type of interview "are typically asked of each interviewee in a systematic and consistent, order, but the interviewers are allowed freedom to digress; that is, the interviewers are permitted (in fact, expected) to probe far beyond the answers to their prepared standardized questions" (Berg, 2009, p. 107), which was what occurred in this research. Moreover, all participants were asked probing questions as relevant information became apparent during the observations. Interviews conducted with the school principal and teacher were conducted individually; those for the students were mostly in small groups. The researcher adapted the interviews depending on how the students wanted to have these oral conversations, individually or with their classmates.

Interviews lasted between 20 to 30 minutes. The researcher let the participants know that the conversations were going to be audio-recorded and that these could be stopped at any time. Also, participants were made aware that they were able to decide the time and place for the interviews to be conducted. With regards to the written questionnaire, it was applied only to students and they were asked similar questions to those asked in the interviews, for example, questions about the language(s) they speak, their language preference, the language they identify themselves with and their attitudes towards both the Tsotsil and Spanish languages. Also, they were asked about the Tsotsil and mestizo cultures.

The conversations with the participants were recorded and translated from Spanish or Tsotsil into English. The interviews were transcribed in order to analyze them through content analysis, which Berg (2009) defines as "a careful, detailed, systematic examination and interpretation of a particular body of material in an effort to identify patterns, themes, biases, and meanings" (p. 338). The identified units of analysis were used for coding the data (e.g., phrases, themes). After that, the researcher open coded the transcript data using the unit of analysis (Berg, 2009) "by asking specific and consistent set of questions, analyzing the data minutely, frequently interrupting the coding to write a theoretical note, never assuming the analytic relevance of any traditional variable such as age, sex, social class, and so on until the data show it to be relevant" (pp. 354-355). The researcher identified the common themes that emerged from the conversation and then she categorized them into coding frames. In addition, the findings were based on the researcher's observations and field notes.

\section{RESULTS AND ANALYSIS}

The following section provides information on the focus school as well as the themes that were identified from collecting data from the Tsotsil teacher, the school principal and the third graders. The results show the participant's attitudes towards the indigenous language as well as how it has been used at the bilingual school. Indigenous teachers working at the focus institution are committed to the maintenance and transmission of the indigenous language and traditions. Therefore, Tsotsil children have been given the opportunity to participate in meaningful activities that have allowed them to use their native language and culture through bilingual discussions, debates, artistic works, creation of poems, singing of songs, games and group activities related to their indigenous roots. Interestingly, the type of bilingual education these students have received has not only had a great impact on the way they perceive Spanish, Tsotsil and both cultures, but also on their openness to and curiosity for other languages. It is possible to say that the type of 
education implemented at the research school has contributed to maintain the Tsotsil language and traditions.

The school has 1 principal, 8 teachers and 227 students who are mostly Tsotsil children. The school was founded in 1990 and is located in Tentic, which is a small town that belongs to the municipality of Chamula in the State of Chiapas.

\section{A. The Teacher}

Josefina (pseudonym), the students' teacher, is a female Tsotsil instructor who also took part in this study. She is in her early forties and is originally from Venustiano Carranza, Chiapas. Her first language is Tsotsil, but she also speaks Spanish as her second language as she was taught both languages by her parents as stated in the conversation the researcher had with her:

Josefina: Tsotsil is my first language. In my hometown, since we're little we learn Tsotsil; we learn both Spanish and Tsotsil, we're bilingual from a very young age. We learn both languages. Of course, there are also families who don't know the native language; they are monolingual in Spanish as they weren't taught Tsotsil by their parents. In my case, my parents taught me both at home; mostly Tsotsil, but I'm fluent in both. Children here are monolingual in Tsotsil, so Spanish is difficult for them. It's important to teach children words in Tsotsil. Parents should also teach them Tsotsil...so the language doesn't disappear. (Josefina Perez, interview by Karla Del Carpio,"Tsotsil children and bilingual education in Chiapas, Mexico: The social and academic consequences of considering or not indigenous children's language and culture in education", Spanish Academic Editorial, August 2017).

Josefina is aware of the importance of transmitting the native language to younger generations as this can help prevent language loss so she ensures to use Tsotsil in the classroom as well.

Josefina holds a four-year bachelor's degree in Pedagogy which she earned from the National Pedagogic University (Universidad Pedagógica Nacional (UPN)) in San Cristóbal de las Casas. While doing her bachelor's, she took courses in pedagogy, culture, interculturality, research methods, Spanish and other courses. Her professors were from different regions in Chiapas. She feels that the contents she learned at UPN were useful; however, she also mentioned that she was not taught how to teach with a bilingual approach as observed in part of the conversation I had with her:

Josefina: The contents I learned at UPN were useful as I was taught how to interact with young children and how to teach them...they taught us different strategies. However, they didn't teach us how to teach with a bilingual approach. They only taught us what they had on their syllabus...bilingual education wasn't part of it. We didn't have bilingual professors, most of them were monolingual in Spanish...well maybe there were bilingual professors, but I didn't have one (Josefina Perez, interview by Karla Del Carpio, "Tsotsil children and bilingual education in Chiapas, Mexico: The social and academic consequences of considering or not indigenous children's language and culture in education”, Spanish Academic Editorial, August 2017).

Interestingly, the latter has been a common situation among teachers working at bilingual schools in indigenous areas, that is, they are not strongly trained to teach with a bilingual approach. Another participant in this research was the school principal.

\section{B. The School Principal}

Antonio (pseudonym), the principal of the elementary school, is a mestizo male in his late 40's who has been teaching at the research school for the last 5 years. His first language is Spanish, but he also speaks Tsotsil and Tzeltal. The latter is another indigenous language spoken in Chiapas. Antonio declared that at the beginning of his teaching career, he did not know he had a passion for teaching as his initial profession was in Economics. This can be observed in part of the conversation the researcher had with him in which he provided some information on his academic and professional journey as well the love he developed for teaching:

School principal: I'm from Panteló, Chiapas. But, I left my hometown when I was 6 years old. I studied in Yajalón for a year then from second to fourth grades I was in Panteló, from fifth grade to upper grades, I studied in San Cristóbal. I was 11 years old when I moved there. I have a Bachelor's Degree in Economics from the Faculty of Social Sciences in San Cristobal. After that, I started a career in teaching. I worked for the state government for 3 years and then I started teaching. Teaching was definitely my vocation, but I didn't know this in the past. Due to financial reasons, I wasn't able to study what I wanted. I wanted to pursue a career in Law, but I couldn't do so. When I was completing my undergrad studies, I had to work in the morning and I went to school in the evening. I'm an Economist, but it's difficult to get a job with this profession plus the pay is really low too. Therefore, I went for teaching. It was the financial need that pushed me to go into teaching. Moreover, I speak 2 indigenous languages.

Researcher: Which ones?

School principal: Tzeltal and Tsotsil, so I applied for a teaching position in an indigenous school. Having a bachelor's degree and being able to speak indigenous languages made it easy for me to get a job at an elementary school. I just had to take a teaching course. I was sent to Chalchituitan, Chiapas as the school principal at an elementary school there.

Researcher: Can you please tell me about your experience there?

School principal: I didn't have any experience as a school principal. I didn't know how to organize things. However, I started learning about this little by little. There was a teacher at the school that wasn't able to teach 
for one week as he was sick, so I had to substitute him. That was my first time teaching children. That's when I discovered my vocation as a teacher. When I saw how children participated in class; how affectionate they were with me...how much they shared, for example, they always gave me fruits such as bananas, pineapples and papayas. Children always showed me their affection. This was really motivating. That's how my vocation for doing service started; service to children. This makes me happy. I've had other job opportunities to work as an Economist; however, I don't want to change my teaching job as teaching makes me happy; it makes me feel complete; I give everything for children. (Aurelio Rodriguez, interview by Karla Del Carpio, "Tsotsil children and bilingual education in Chiapas, Mexico: The social and academic consequences of considering or not indigenous children's language and culture in education", Spanish Academic Editorial, August 2017).

One of the positive aspects is that most of the indigenous teachers working at the focus school are committed to the maintenance and transmission of the indigenous language and traditions. However, they are not necessarily trained to teach with an intercultural bilingual approach as their academic background is not always in teaching, but on a different area. Also, there are instructors who go into the teaching field without planning to do so or without knowing they have an interest in it. However, they choose to become teachers as it represents employment and financial opportunities. Through the numerous observations and interactions, the researcher had with the school principal, she noticed that although he does not have a background in teaching, he has become an efficient and caring instructor who is definitely committed to his students, colleagues and the teaching field. The researcher observed that the students the school principal works with love him and enjoy being around him. This is evidenced by the fact that it is them who many times take the initiative to go to the main office just to say hello to him, to give him a hug or to share some of their fruits or vegetables with him. Antonio's caring and approachable personality has fostered this positive attitude in the students.

\section{The Third Graders}

This research also had the participation of 25 indigenous Tsotsil third graders. All of the students' first language is Tsotsil and are in the process of learning Spanish as their second language. Most third graders understand Spanish, but do not speak it fluently, so they feel more comfortable when communicating in Tsotsil. There are third graders who are monolingual in Tsotsil, so the school is their first contact with the Spanish language. All of the students were born and raised in Tentic. Unfortunately, most of these children live in a disadvantageous situation as they live in extreme poverty. The poverty in which these Tsotsil indigenous children in Chiapas live coincides with the reality lived by other indigenous children in different parts of Latin America, for example, in Peru where it has been found that the inequities experienced by Peruvian children are directly related to their ethnic origin (Group for the Analysis of Development (GRADE), National Institute of Statistics and Informatics (INEI) \& United Nations Children's Fund (UNICEF), n.d. as cited in Inversión en la Infancia, 2010). "Indigenous young children and adolescents who learned to speak Quechua, Aymara or any Amazonian language live in worse conditions and have less access to better development opportunities than those whose first language is Spanish" (Inversión en la Infancia, 2010, para. 2). It is among the indigenous population where "the highest negative ratings of poverty, healthcare, education and identity are found" (Inversión en la Infancia, 2010, para. 2,). A clear example of this is the Tsotsil children who took part in this research.

Most Tsotsil children have positive attitudes towards their first language and Spanish. However, it was noticed that when they were asked questions in class, they respond in Tsotsil. Also, the language mostly spoken in the classroom and at the school in general is Tsotsil. In other words, the use of Tsotsil in the classroom is predominant, which was confirmed by the teacher who mentioned that when students get to grade 3, the language they know and speak the most is Tsotsil.

It was noticed that the third graders' teacher and her colleagues have positive attitudes towards the native language and culture, this has influenced their teaching practice, which has had an impact on students' attitudes. When students were asked about the language(s) and culture (s) they identify themselves with all of them answered they identify with Tsotsil. Here are some examples:

Student A: I identify with Tsotsil because it is my mother tongue. I feel good when I speak it. I don't speak Spanish.

Student B: The Tsotsil culture is a pretty culture that has always lived in Chiapas through the traditional clothing, the indigenous language, the way of being... the Tsotsil people's traditional stuff has also being sold abroad.

Student C: I speak Tsotsil. My family doesn't speak Spanish. I identify with my indigenous language.

Student D: We like Tsotsil and we also preserve our traditions. We weave and embroider. But, boys don't know how to do those activities. Boys only know how to cultivate the land, they grow pumpkins or beans. Sometimes they don't come to school because they have to go seed or because they get sick.

Student E: I like Tsotsil because there are things we can only say in Tsotsil. There are things we can't translate into Spanish, for example, when we talk about clothes or things like that. There are certain things we can only say in Spanish. We write more in Spanish...sometimes in Tsotsil. We can write a letter in Tsotsil, but it's easier to write in Spanish. But, we can also write a story in Tsotsil. Our textbooks are mostly in Spanish (Tsotsil students, interview by Karla Del Carpio, "Tsotsil children and bilingual education in Chiapas, Mexico: The social and academic consequences of considering or not indigenous children's language and culture in education”, Spanish Academic Editorial, August 2017). 
Also, as it can be seen in the previous quote, the fact that they have positive attitudes towards their native language and culture does not imply they reject the Spanish language. In other words, students seem to also have positive attitudes towards Mexico's dominant language and culture as can be seen in the following excerpts:

Student A: The mestizo culture is nice. It is good to learn to speak Spanish because it is a pretty language.

Student F: I also like Spanish other than Tsotsil.

Student G: I identity with Tsotsil, but I like both Spanish and Tsotsil. We speak both.

Student H: I like both languages. We like both languages here (Tsotsil students, interview by Karla Del Carpio, "Tsotsil children and bilingual education in Chiapas, Mexico: The social and academic consequences of considering or not indigenous children's language and culture in education”, Spanish Academic Editorial, August 2017).

Interestingly, other than having positive attitudes towards Spanish and Tsotsil, they seem to have curiosity and interest in the learning of other languages such as English, French and Chinese:

Student I: When I get to junior high school, I'd like to learn English because I like it. They say that English is easier than Tsotsil so it'd be easier for us to learn English.

Researcher: Why would you like to learn English?

Student I: Sometimes we meet people who speak English, but we don't understand them. We like English because we'd like to learn animal names in English so we can translate them into Spanish and Tsotsil.

Student J: We'd also like to learn French and Chinese (Tsotsil students, interview by Karla Del Carpio, "Tsotsil children and bilingual education in Chiapas, Mexico: The social and academic consequences of considering or not indigenous children's language and culture in education”, Spanish Academic Editorial, August 2017).

The previous conversation is an example of the positive effects of bilingual education. In this case, the type of bilingual education these students have received has not only had a great impact on the way they perceive Spanish, Tsotsil and both cultures, but also on their openness to and curiosity for other languages. It is possible to say that the type of education implemented at the research school has contributed to maintain the Tsotsil language and traditions. An example of this is the fact that students at this school do not have to wear a uniform every day except for Monday which is when they have the traditional national homage. This provides students with the option of wearing their typical indigenous outfit, offering them the option to decide whether they want to wear their traditional clothing or the uniform.

At the focus school, indigenous children have been given the opportunity to participate in meaningful activities that have allowed them to utilize their native language and culture which can be done through bilingual discussions, debates, artistic works, creation of poems, singing of songs, games and group activities related to their own indigenous culture while using both their native and second languages. In the following section some of these activities are described.

\section{Activities to Preserve and Promote the Tsotsil Language and Culture}

Theater has been a valuable tool to share some of the traditions of the Tsotsil community. The teachers stated that the use of art is an educational proposal that highlights various social functions. The Secretary of Public Education (SEP) (2006) points out that art is a source of discovery for the student therefore it is used to produce crafts, put on shows for school festivities and different events to promote children's languages and cultures. Tsotsil teachers have done a phenomenal job motivating and preparing their students to participate in plays, which has allowed the Tsotsil language to be used in an artistic setting at the local and national level. This has been done as part of the National Indigenous School Theater project in Mexico.

Teachers have also created poetry contests at the school which have given Tsotsil children the opportunity to write poems in their mother tongue. The content of many of these poems reflects some of the traditions of the town, as well as the Tsotsil cosmovision. Teachers choose a date for the children to recite their poems in front of the rest of the students and teachers. This event at the school is known as the "Top Ten Poetic." The Tsotsil culture has also been spread through the typical dances of the region in which the dancers are the Tsotsil children themselves. Furthermore, it is admirable that the Tsotsil children with the help of their teachers have translated songs from English or Spanish into the Tsotsil language. These songs have been performed in Tsotsil at events such as festivals or ceremonies within the school. It was fascinating to observe the interest and curiosity that these children have for other languages and cultures, but not at the expense of their own, that is, they want to learn about other communities and their languages, but always maintaining their indigenous language and culture. Olcina-Sempere (2018) emphasizes that music in today's society must be viewed from a multicultural perspective. Therefore, it is necessary to "incorporate the music of different cultures at all educational levels, reformulate the contents and strategies, and develop new teaching materials (Kraus, 1967; Bruhn, 2010; Rodríguez-Quiles, 2013)" (Olcina-Sempere, 2018, p. 63). Music can therefore be a resource that contributes to the development of intercultural competence. In the case of children, from a very young age, their environment is influenced by music, which can be used to develop intercultural competence in them, which is being carried out in the children who participated in this ethnography.

The fact that the focused Tsotsil children have used their native language and aspects of their culture in bilingual discussions, debates, artistic works, creation of poems, singing of songs, games and group activities while using both their native and second languages have contributed to raise the status of the Tsotsil language. Also, this type of activities has helped promote collaborative work and create a peaceful/harmonious environment in the classroom where 
students' affective filters are open to welcome and practice the target language since enriching interactions that embrace diversity in all its dimensions are promoted. In other words, these artistic activities have allowed indigenous children to coexist with each other, get to know each other better, and develop their language skills, just to mention some of the benefits of such activities. On the other hand, the fact that these little ones can socialize and build healthy relationships with their peers fulfills one of the many characteristics of education; the social aspect of it. It is important to remember that education is a social process in which each child must have the opportunity to live with others and with their environment in order to continue growing, learning and maturing. It is true that education happens throughout life and not just within school. However, it is essential that in this space the child has enough opportunities to interact with their peers, which is beneficial since through these interactions they can learn not only from the "other" but also from themselves. The implementation of quality education is fundamental for the progress of any society since its original purpose is to be a valuable tool that enriches the student through knowledge that allows them to grow academically and staff in addition to developing.

\section{DisCUSSION AND RECOMMENDATIONS}

The fact that the teachers who work at the research school are Tsotsil and have positive attitudes toward their native language and culture increases the possibilities of using the indigenous language at school. This is an asset as it strengthens the preservation and promotion of the native language. According to the UNESCO's (2003) Language Vitality and Endangerment report, "a language is endangered when it is on the path towards extinction . . . when its speakers cease to use it, use it in an increasingly reduced number of communicative domains, and cease to pass it on from one generation to the next. That is, there are no new speakers, either adults or children" (p.3). In the case of the Tsotsil community, their native language is mostly transmitted from elders to younger generations as in some cases it is the only language spoken by older generations. Therefore, in order for communication to take place between, for example, grandparents and grandchildren, the indigenous language needs to be learned.

Since Tsotsil is widely used in the town and also at the school, the indigenous language is in an active and living situation, which decreases the chances of putting it in danger of disappearance which has been the case of many minority languages not only in Latin America, but in different parts of the world. It should be noted that the researcher is not suggesting that using the Tsotsil language as the current dominant language both in the town and at the school guarantees its preservation in the future as languages are always evolving/changing as well as their situation because they reflect the modifications taking place in society. What the researcher is saying is that the Tsotsil language does have an active role in the town and such a role is being supported at school as the teachers speak it both inside and outside of the classroom. Also, it is the primary language spoken by the students. This situation reinforces the vitality of the native language as its use is supported in an academic environment, which has not been a common practice. It is true that schools alone are not enough to revitalize indigenous languages as this occurs "within an ecology of languages, in a context of other local and global languages with their relative statuses and uses in domains and social fields such as employment, religion, government, cultural life, media and others" (Hornberger, 2011, p.1). Also, native language revitalization is "subject to the vagaries of policy, politics, and power; and it is subject to the economics of the linguistic marketplace (Hornberger, 2011, p.1). Nonetheless, the use and promotion of native languages in education is an essential tool that can help their revitalization or strengthening. Also, education can help elevate the status of these languages.

In the case of the Tsotsil language, it is used as a language of instruction at the research school. However, its use could be increased if all of the instructors received more training on how to teach with a bilingual approach. The lack of training has been a common barrier in bilingual schools. It should be mentioned that although they lack such a training, they do teach using both languages especially in higher grades such as fourth, fifth and sixth grades. However, in other Spanish-Indigenous elementary bilingual schools, there is tension between languages since it is usually the dominant language that is more privileged when teaching instead of both.

The fact that teachers have developed different activities where students can use their first language and aspects of their culture is very positive since it allows students to use their L1 in a creative way. Now more than ever, it is important that teachers find ways to develop students' creativity which "implies managing knowledge with flexibility: the notion that man is capable of structuring and integrating knowledge in many ways, also in new, unusual ways, which can lead to new, unique solutions (p. 3-4)" (Roeders, 2005, cited in Jane, 2013, para.7). To achieve this objective, it is necessary for teachers to being updated with respect to renewed methodologies. For this reason, it is essential for them to receive training courses or workshops that enrich their teaching practice and equip them with various techniques to stimulate the student's creativity and for them to have an active role in their own learning. One of the first steps to achieve this goal is to reflect on the real meaning of education so that significant improvements can be made with the aim to benefit students especially those from linguistic minority groups such as indigenous children.

\section{Reflecting on Education}

Campanas (2012) points out that the concept of education involves promoting the development of feelings, convictions and the character of the student. Therefore, it is important that teachers pay attention to the student's personality, their needs and interests to look for the best ways to guide them, which could be observed by the teacher and school principal who participated in this research study. On the other hand, it is worth emphasizing that education 
and instruction are not the same. Education involves guiding and accompanying the student in the process while instruction involves teaching "the correct answer." In this regard, Eriesco (2016) emphasizes that:

Education is about personal development and growth, achieving your goals, earning your bread, being happy, etc. In schools "the correct answer" has always been taught. This is not education, but instruction, a form of indoctrination. While this enslaves you, true education sets you free, shows you various options, and allows you to choose. True education does not impose on you; it does not demand from you or punish you for not knowing how to do something but offers you possibilities and helps you (para. 1).

Therefore, quality education should lead to liberation, not to oppression or imposition of the truth of the teacher or of a certain group of people in the dominant society. Unfortunately, the school, the educational system and instructors' teaching practice have been characterized by being that of controlling and domination. "One of the ways in which this dominating force is mostly exerted comes from a type of analytical and conceptual education" (Hernández \& Mariño, 2017, p. 9) which should be explored and modified. This reality of imposing and controlling education should invite us to reflect on the numerous times in which students especially those from linguistic minority communities such as indigenous students, have been imposed a "correct answer." In other words, we should reflect on to what extent indigenous students have been instructed or educated. On the other hand, it is also worth reflecting on the implications that instruction has and has had on these students, for example, we should explore the multiple ways that have been used to silence indigenous children through an educational system that preserves and only promotes the dominant language of the country instead of promoting all the multiple languages that are in the nation which has resulted in monolingualism in the dominant language and the assimilation of linguistic minority groups to mainstream society.

Calvo (2001) argues that imposing a partial and relative truth eliminates "the wonder of the mystery" (p. 7) and what is actually done is the promotion of superficial generalizations that decrease the chances of stimulating students' enthusiasm. In addition, it destroys the confidence that they have in themselves. Other consequences of imposing a partial and relative truth is that the adventure of knowing is eliminated, the theory is devalued and students are subjected to what is considered "concrete" (Calvo, 2001, p. 7). This significantly minimizes some of the teacher's tasks such as stimulating the self-responsibility and creativity of each student.

Now more than ever, it is important to remember and put into practice the real meaning of education to ensure that all students especially those who have been historically marginalized and excluded, indigenous children, for example, receive quality education that affirms their cultural and linguistic identity by using their funds of knowledge as an essential tool in the teaching and learning process. By doing so, indigenous children's language and culture will be respected, preserved, and promoted. Therefore, it is fundamental to finds ways to improve the current type of education that is implemented to indigenous children which is one of the main reasons that motivated the research study that was described in the previous sections. Moreover, if the current type of education that indigenous children receive improves, the possibilities for structural racism, discrimination and exclusion and the continuation of colonial policies and practices to continue to happen may decrease. Let us not forget that the negative attitudes towards indigenous communities are rooted in an unfair history that ignored their cultural and linguistic rights where they were thought as human beings, but historically and culturally different. Moreover, they were considered to be undeveloped therefore it was thought they did not deserve to be recognized as citizens (UNAM, 2001). Indigenous communities have been denied of their basic rights and have suffered the consequences of colonial domination. The state has perpetuated structural inequalities therefore these groups have experienced neglection, destitution and abuse. Situation originated in the past, but that continues to have a strong influence in today's society. Therefore, one of the main recommendations based on the findings of this research study is to make education become quality inclusive education so that repeating the same historical mistakes that have violated the rights of indigenous communities stop taking place. Also, indigenous languages need to be given an active role in education and other formal domains such as the government, media, public institutions, etc. By doing so, indigenous languages could be preserved, promoted and their status could be elevated.

\section{CONCLUSION}

Significant work still needs to be done in Mexico to actually accept and promote the many identities that there are in the nation. The first step is to recognize diversity as something that enriches us rather than something negative. By doing so, the possibilities for new actions and public policies would be created and would replace the old assimilationist ones that have characterized the educational system. Only when we recognize and promote that Mexico has more than one face (the dominant society's face), that is, that it has more than 65 indigenous faces is when we will be able to say that Mexico is a multicultural and multilingual nation. Now more than ever, we need to work together as a community to improve the type of education indigenous children receive to ensure that their voice is taken into account into the content they learn and the type of activities they are asked to do. The Tsotsil children who participated in this research study show that with the help of teachers, it is possible to maintain and promote indigenous languages and cultures through artistic activities. The findings of this ethnography show that indigenous children are active agents of cultural and linguistic preservation and promotion as evidenced by all the work they have done to make education more humane which should motivate us to follow their example. 


\section{ACKNOWLEDGMENTS}

This work was enriched by and the researcher gives thanks to the instructor, school principal and indigenous students who took part in this research study. The researcher feels extremely grateful to the young Tsotsil children who participated in the study. She thanks them for sharing their joy, time and wisdom with her, for letting her learn from and about them, their language and culture. It is thanks to them that the researcher was able to gain a better understanding of the topic she explored in this research. She also thanks these children for sharing their food and resources with her, for being one of the best examples she has to show that bi/multilingualism is possible despite disadvantageous living conditions and the lack of financial resources. The researcher would also like to thank the children's parents for granting consent for their sons and daughters to take part in this work. I thank them for their trust.

\section{REFERENCES}

[1] Berg, B. (2009). Qualitative research methods for the social sciences ( $7^{\text {th }}$ ed.). Toronto: Allyn \& Bacon.

[2] Calvo, C. (2001). Los niños y la propensión al aprendizaje. Congreso Europeo: Aprender a ser, aprender a vivir juntos Santiago de Compostela, diciembre 2001. Retrieved June 4th, 2020 from sitio http://www.waece.org/biblioweb07/pdfs/d201.pdf.

[3] Campanas, E. (2012). Diferencias entre educación e instrucción. Retrieved July 4th, 2020 from https://www.scribd.com/.

[4] Chacón, O. (2005). Teoría de los derechos de los pueblos indígenas; problemas y límites de los paradigmas políticos. Universidad Nacional Autónoma de México.

[5] Del Carpio, K. (2017). "Tsotsil children and bilingual education in Chiapas, Mexico: The social and academic consequences of considering or not indigenous children's language and culture in education”, pp. 1-267, ISBN: 978-3-659-65833-4, Editorial Académica Española.

[6] De Varennes, F. (s.f.). Language, rights and opportunities: The role of language in the inclusion and exclusion of Indigenous peoples. Paper not published.

[7] Eriesco, L. (2016). La diferencia entre educación e instrucción. Encontrado el 24 de julio de 2019 en el sitio https://luisriesco.wordpress.com/2016/12/09/la-diferencia-entre-educacion-e-instruccion-2/.

[8] Hernández, N. \& y Mariño, C. (2017). Multidiversidad de y para niñas y niños (Manuscrito doctoral). University of La SalleCosta Rica.

[9] Hornberger, N. (2011). Can schools save indigenous languages? Policy and practice on four continents. New York: N.Y. Palgrave Macmillan.

[10] Instituto Nacional de Estadística y Geografía (INEGI). (2010). Principales resultados del Censo de Población y Vivienda 2010. Retrieved August 18th, 2020 file:///C:/Users/Karla/Documents/Etnografía\%20CHENALHO/Texts/INEGI\%202010.pdf.

[11] Inversión en la Infancia. (2010). Inversión en la infancia. Retrieved September $6^{\text {th }}, 2019$ from https://inversionenlainfancia.net/

[12] Jane, J. (2013). El rol del docente en el proceso de enseñanza-aprendizaje. Retrieved June 28th, 2020 from https://janijanett.blogspot.com/2013/06/el-rol-del-docente-en-el-proceso-de.html.

[13] Kawulich, B. (2005). Participant Observation as a Data Collection Method [81 paragraphs]. Forum Qualitative Sozialforschung / Forum: Qualitative Social Research, 6(2), Art. 43, Retrieved March 2 ${ }^{\text {nd }}, 2019$ from http://nbn-resolving.de/urn:nbn:de:0114fqs 0502430.

[14] López, L. (2009). Reaching the unreached: indigenous intercultural bilingual education in Latin America. Paper commissioned for the EFA Global Monitoring Report 2010, Reaching the marginalized. Retrieved February 27, 2019 from http://unesdoc.unesco.org/images/0018/001866/186620e.pdf.

[15] Olcina-Sempere, G. (2018). "La música como instrumento para el fomento de la educación intercultural,” En Cultura de paz y buen trato a la infancia coord. por Jiménez et al., 2018, ISBN 978-84-09-05740-5, págs.. 61-71, CIPI Ediciones, Huelva, España.

[16] The Secretary of Public Education (SEP). (2006). Educación básica. Secundaria. Artes. Teatro. Programas de estudio, Ciudad de México, México.

[17] United Nations Educational, Scientific and Cultural Organization (UNESCO). (2003). Language vitality and endangerment UNESCO ad hoc expert group on endangered languages. Retrieved June 27, 2019 from http://www.ice.ge/kartuliena/pages/unesco/1e.pdf

[18] Universidad Autónoma de México. (UNAM) (2001). Chiapas. Instituto de Investigaciones Economicas, UNAM, México.

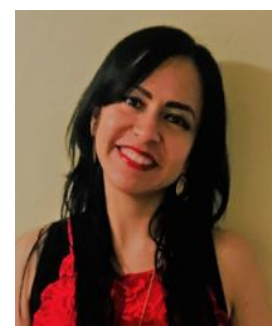

Karla Del Carpio is currently Associate Professor in the Department of World Languages and Cultures at the University of Northern Colorado. She earned her bachelor's degree in Teaching English as a Foreign Language from the Autonomous University of Chiapas in Mexico, her master's degree in Applied Linguistics from the Department of Modern Languages and Cultural Studies of the University of Alberta (UofA) in Canada and her PhD in Secondary Education from the Faculty of Education of the UofA. Dr. Del Carpio has won different awards in Canada, Mexico and the United States, for example, she received the 2011 Zita and John Rosen Teaching Award in Canada, the 2013 National Academic Achievement Award in Mexico and the 2020 Humanities and Social Sciences Excellence in Teaching Award in the United States. Her research interests are in the areas of second language acquisition, teaching English as a second language, bilingual education, indigenous languages revitalization and promotion and linguistic human rights. 